\title{
Seasonal dynamics of cyst formation of strombidiid ciliates in alpine Lake Mondsee, Austria
}

\author{
Helga Müller*, Peter Stadler, Thomas Weisse \\ Institute for Limnology of the Austrian Academy of Sciences, Mondseestr. 9, 5310 Mondsee, Austria
}

\begin{abstract}
The seasonal dynamics of strombidiid ciliates in alpine Lake Mondsee, Austria, were studied from September 1999 to November 2000 and in April/May 2001. Simultaneously, their resting cysts were collected in sediment traps. Concentrations of active strombidiids at 0 to $20 \mathrm{~m}$ depth

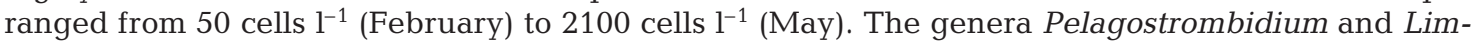
nostrombidium coexisted during all seasons, with Pelagostrombidium being the dominating taxon, contributing 70 and $83 \%$ to total strombidiids in September 1999 and May 2001, respectively. Throughout the study period, only 1 cyst type was observed, which in size and shape matched a previous description of Pelagostrombidium cysts. Maxima of cyst production (up to $2 \times 10^{5}$ cells m$^{-2} \mathrm{~d}^{-1}$ ) occurred in October/November, while virtually no cysts were detected in winter, spring and early summer. The absence of a spring maximum of cyst formation contrasts with earlier observations from pre-alpine Lake Constance. We explain this finding by a different timing of strombidiid development, relative to the phytoplankton spring bloom in both lakes.
\end{abstract}

KEY WORDS: Pelagostrombidium · Limnostrombidium · Cyst · Lake Mondsee · Lake Constance Resale or republication not permitted without written consent of the publisher

\section{INTRODUCTION}

Planktonic strombidiid ciliates are common in surface waters of oceans and lakes (Fenchel 1987), and several species can form resting cysts (Reid 1987, Kim \& Taniguchi 1995, Müller 1996, Müller \& Wünsch 1999). Up to now, our knowledge on the function of these resting stages and on the factors triggering encystment is very limited. Relevant studies have mainly been performed with marine ciliates (for a review see Müller 2000). In freshwater, there has only been 1 field study on strombidiid cysts: Müller \& Wünsch (1999) described a pronounced seasonality of cyst formation in pre-alpine Lake Constance, Germany.

The site of the present study was the deep alpine Lake Mondsee, Austria. This lake is similar to Lake Constance in several aspects, such as range of ambient temperatures, stratification and community composition of planktonic ciliates (Salbrechter \& Arndt 1994).

${ }^{*}$ Present address: Jacob-Burckhardt-Str. 18, 78464 Konstanz, Germany. E-mail: helga.mueller.konstanz@t-online.de
Both lakes underwent a period of accelerated eutrophication during the 1960s and 1970s, followed by a strongly reduced phosphorus nutrient load and subsequent re-oligotrophication over the past $20 \mathrm{yr}$ (Häse et al. 1998, Schwarz \& Jagsch 1998). Concerning annual mean and maximum chlorophyll a (chl a) concentrations, and mean total phosphorus content (Häse et al. 1998, IGKB 2000), Lake Constance is currently in a mesotrophic state, according to the OECD classification system (OECD 1982); Lake Mondsee is at present oligo-mesotrophic (Schwarz \& Jagsch 1998). The crustacean zooplankton community and its response to eutrophication and re-oligotrophication differ in these lakes. Lake Mondsee is dominated by copepods in autumn, winter and spring (Dokulil et al. 1990). A pronounced clear-water phase, which is caused by grazing daphnids and characteristic of Lake Constance (Lampert 1978) has never been observed in Lake Mondsee (Dokulil \& Skolaut 1986, Dokulil et al. 1990, Salbrechter \& Arndt 1994).

This field study in Lake Mondsee was performed from September 1999 to November 2000; additional data were collected in April/May 2001. We recorded 
concentrations of strombidiids at 0 to $20 \mathrm{~m}$ depth together with total numbers of planktonic ciliates, chl $a$ concentration and water temperature. The downward settling flux of strombidiid cysts was quantified by the use of sediment traps.

A different seasonal pattern of cyst formation emerged compared to the pattern reported from Lake Constance. We discuss this result, considering general differences in the plankton seasonal succession of both lakes.

\section{MATERIALS AND METHODS}

Study site and periods. Lake Mondsee is an alpine oligo-mesotrophic lake situated in central Austria $\left(47^{\circ} 50^{\prime} \mathrm{N}, 13^{\circ} 23^{\prime} \mathrm{E}\right)$ at $480 \mathrm{~m}$ above sea level. It has an area of $13.8 \mathrm{~km}^{2}$, a mean depth of $37 \mathrm{~m}$ and a maximum depth of $68 \mathrm{~m}$ (Schwarz \& Jagsch 1998). Our sampling station was located in the central part of the lake (depth $45 \mathrm{~m}$ ) where water currents due to inflowing rivers and lateral input were presumably low. Study periods were September 9, 1999 to November 21, 2000 and April 10 to June 5, 2001.

Temperature and chl a. Continuous profiles of water temperature $(0$ to $40 \mathrm{~m})$ were recorded at the sampling site at each sampling occasion by means of a thermistor probe (Yellow Springs). Water samples for chl a measurements were obtained by an integrating Schröder water bottle (Züllig) over the upper $20 \mathrm{~m}$ of the water column. The volume of the water bottle was $800 \mathrm{ml}_{i}$ it collected $40 \mathrm{ml} \mathrm{m}^{-1}$ during a vertical haul. Results, therefore, represent mean chl a values from 0 to $20 \mathrm{~m}$. Chl a was measured after hot ethanol extraction according to Nusch (1980).

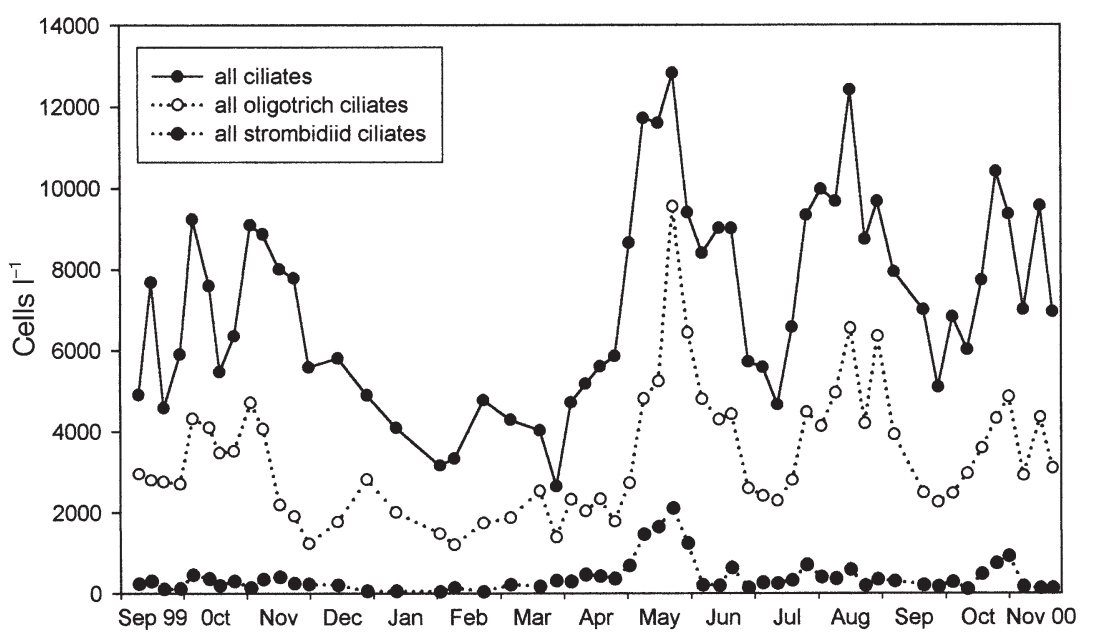

Fig. 1. Ciliate cell concentrations in Lake Mondsee at 0 to $20 \mathrm{~m}$ depth from September 9, 1999 to November 21, 2000
Cell concentrations. Water samples were taken weekly during the growing season with an integrating Schröder water bottle over the depth interval 0 to $20 \mathrm{~m}$. Since strombidiid ciliates are known to live rather close to the lake surface (Müller et al. 1991), we did not take samples from below $20 \mathrm{~m}$. In winter, sampling intervals were $2 \mathrm{wk}$, except for one $3 \mathrm{wk}$ interval in January when the lake was frozen. Samples were fixed with acid Lugol's solution and used for counting ciliates with the Utermöhl technique (cf. Müller 1989). All planktonic ciliates were counted in $50 \mathrm{ml}$ subsamples; $100 \mathrm{ml}$ subsamples were scanned for strombidiids. In April/May 2001, only the strombidiids were recorded. Phytoplankton cell concentrations were determined by Claudia Skolaut (Institute for Limnology, Mondsee) in parallel to the present investigation with standard methods (Dokulil \& Skolaut 1986).

Taxonomy. We use the term 'oligotrich ciliates' in the sense of the Oligotrichida Bütschli, 1887, as characterized by Foissner et al. (1999). Regarding strombidiid ciliates, we followed the nomenclature of Krainer (1991, 1995), who placed freshwater strombidiids into the newly established genera Limnostrombidium and Pelagostrombidium. In counts of Lugol-fixed samples, these 2 genera cannot be separated quantitatively, whereas they are easily recognized in protargolstained material. Therefore, $500 \mathrm{ml}$ water samples from 0 to $20 \mathrm{~m}$ depth were taken on 3 occasions (September 9 and 15,1999, and May 22, 2001) and fixed with $\mathrm{HgCl}_{2}$ (final concentration: $0.6 \mathrm{~g} \mathrm{l}^{-1}$ ). The samples were concentrated by sedimentation and centrifugation to a volume $<0.5 \mathrm{ml}$; protargol-stained slides were prepared from this material following the protocol of Foissner (1991). The slides were scanned for strombidiids at 400 -fold magnification to determine the ratio of Limnostrombidium:Pelagostrombidium. We did not attempt to identify strombidiid species (see 'Discussion').

Cyst identification and sizing. Pelagostrombidium cysts were identified with light microscopy, following the description of Müller (1996). Cyst dimensions were measured at 200 -fold magnification with a calibrated eyepiece micrometer. Data sets from Lake Constance (Müller \& Wünsch 1999) and Lake Mondsee were compared by the Mann-Whitney rank sum test, using the statistical software SigmaStat (Jandel Scientific).

Flux rates of cysts. Cyst production was measured with sediment traps as described by Müller \& Wünsch (1999). We used the same traps as in this earlier study, with a design recommended by 
Bloesch \& Burns (1980), i.e. cylindrical tubes made of transparent plexi-glas with a height of $100 \mathrm{~cm}$ and an inner diameter of $10 \mathrm{~cm}$. Four replicates of these traps were exposed at $45 \mathrm{~m}$ depth, standing upright on the lake bottom. Müller \& Wünsch (1999) measured a sinking velocity of Pelagostrombidium cysts at $8^{\circ} \mathrm{C}$ of approximately $14.4 \mathrm{~m} \mathrm{~d}^{-1}$. According to Stokes' law, this value will increase considerably with increasing water temperature. Cysts produced between 0 and $20 \mathrm{~m}$ depths, therefore, could have reached the $45 \mathrm{~m}$ depth within 2 to $3 \mathrm{~d}$. The effect of turbulence on settling particles $<500 \mu \mathrm{m}$ is low, as explained in detail by Bloesch \& Burns (1980).

With consecutive exposures, we covered the entire study periods. Routinely, the traps were exchanged weekly. Biweekly exchanges were made from December 1999 to mid-March 2000, except for a period of ice cover in winter: between January 11 and February 1, the traps remained exposed on the lake bottom for $3 \mathrm{wk}$. After trap retrieval, the collected material was sieved through $200 \mu \mathrm{m}$ mesh. The fraction of $<200 \mu \mathrm{m}$ of 1 trap was fixed with acid Lugol's solution for counting and sizing of the cysts. The rest of the material was stored at $4^{\circ} \mathrm{C}$ in the dark for live observation (Müller 2002). The Lugol-fixed subsamples were concentrated by sedimentation and centrifugation, and resuspended in a defined water volume, generally 40 or $80 \mathrm{ml}$, depending on the amount of sediment collected during each exposure. One $\mathrm{ml}$ aliquots of this material were filled into Sedgewick-Rafter-chambers and scanned for cysts at 100-fold magnification. Two to 8 entire chambers were examined, the contents of which was 2.5 to $10 \%$ of the contents of 1 trap. Flux rates (cysts $\mathrm{m}^{-2} \mathrm{~d}^{-1}$ ) were calculated from these counts, the total area of the trap $\left(78.5 \mathrm{~cm}^{2}\right)$ and the exposure time. The protocol described above resulted in a detection limit of approximately 400 cysts $\mathrm{m}^{-2} \mathrm{~d}^{-1}$.

\section{RESULTS}

\section{Ciliate abundance and community composition}

Over the study period 1999/2000, mean concentrations at 0 to $20 \mathrm{~m}$ depth of all planktonic ciliates varied

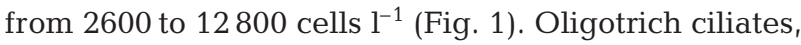
namely strobilidiids, halteriids, strombidiids and tintinnids, were a major component of the community. Taken together, these taxa accounted for $47 \%$ of total ciliate numbers on average. Furthermore, ciliates of the genera Balanion, Urotricha, Coleps, Askenasia and Histiobalantium contributed significantly to ciliate concentrations. Ciliate maxima occurred on May 23 and August 16, whereas only moderate numbers were present in April, when chl a concentrations peaked (Fig. 2).

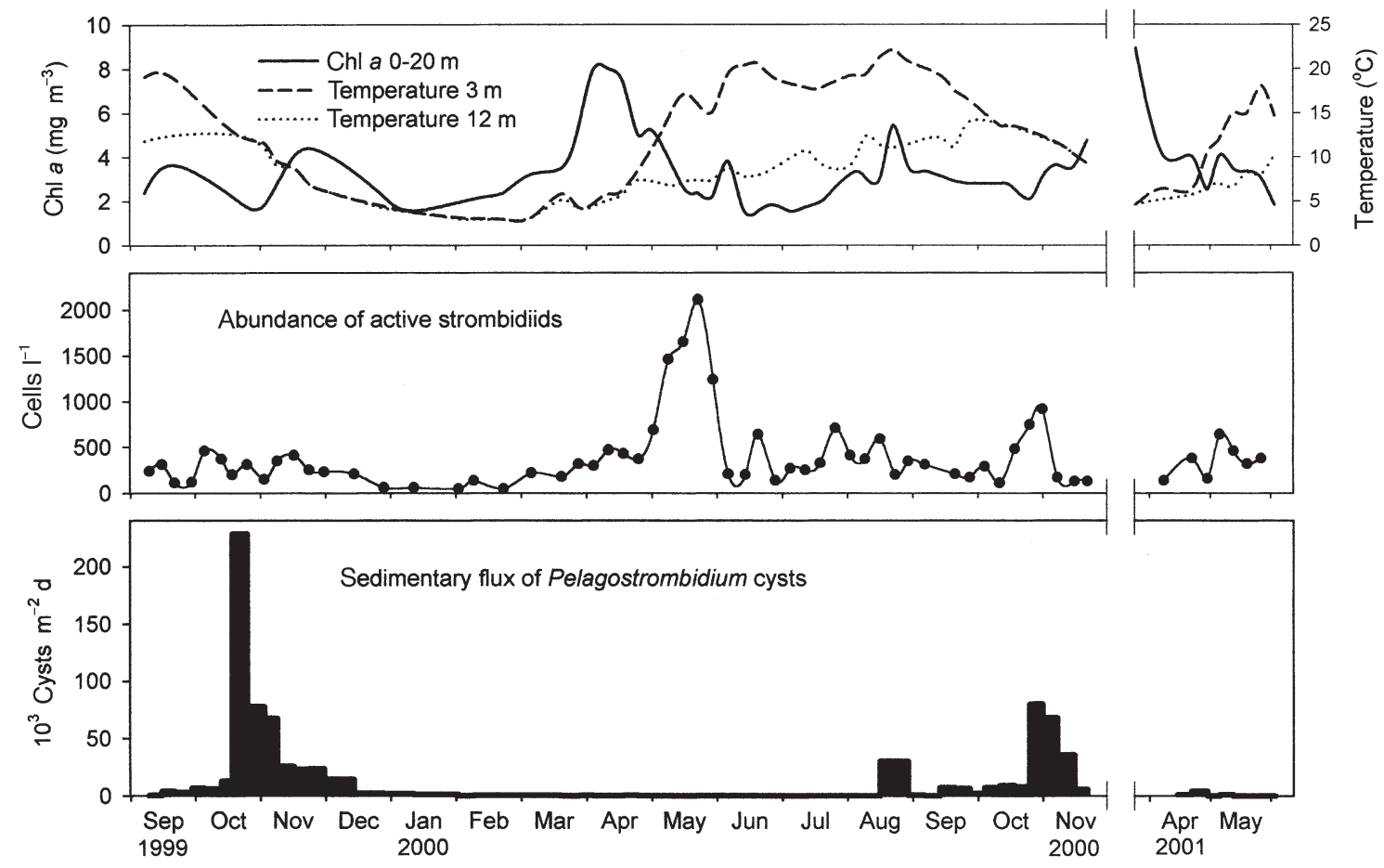

Fig. 2. Dynamics of strombidiid ciliates in Lake Mondsee, September 1999 to November 2000 and April/May 2001. Top: chlorophyll $a$ concentrations at 0 to $20 \mathrm{~m}$ depth and water temperature in 3 and $12 \mathrm{~m}$ depth. Middle: concentrations of active strombidiids at 0 to $20 \mathrm{~m}$ depth. Bottom: flux rates of strombidiid cysts 

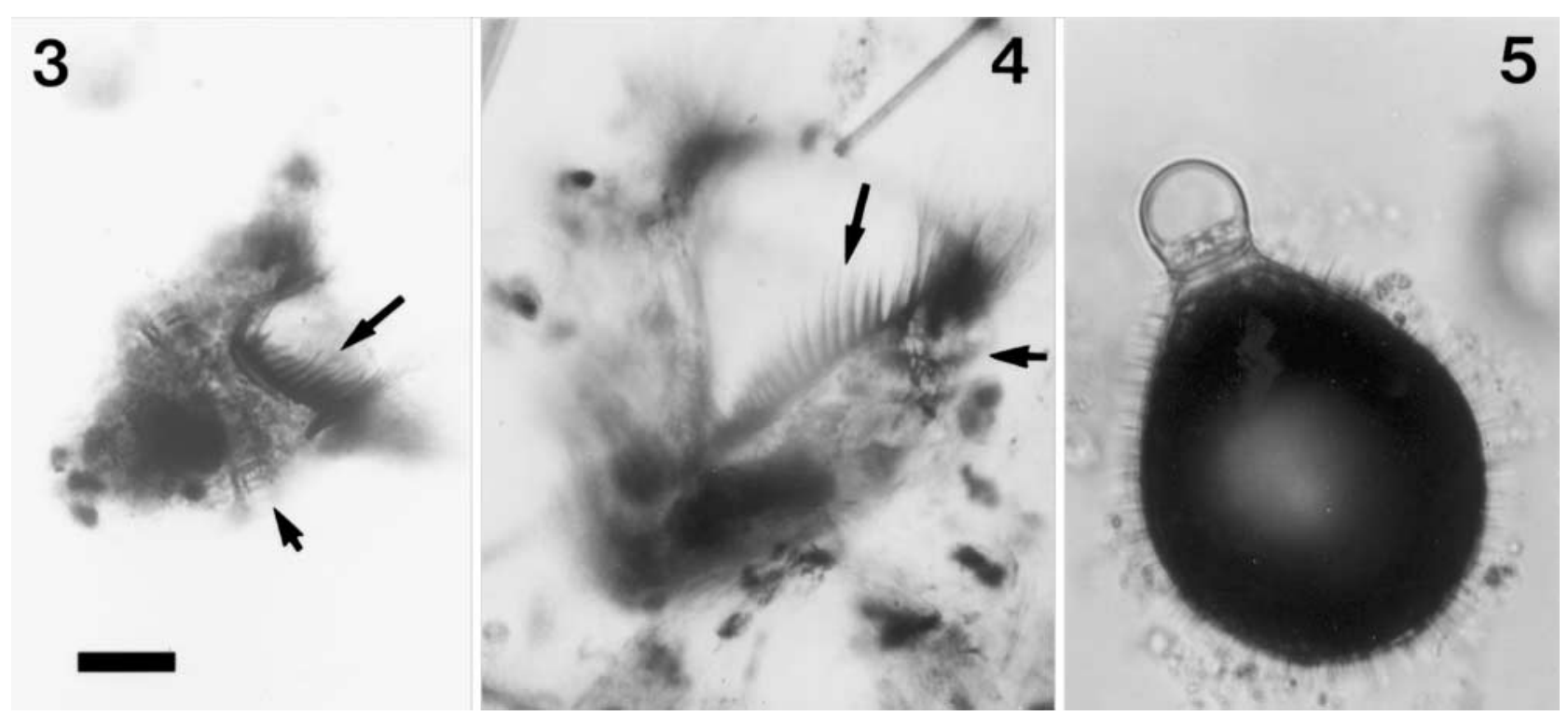

Figs. 3 \& 4. Protargol-stained specimens of Limnostrombidium (Fig. 3) and Pelagostrombidium (Fig. 4) from surface waters of Lake Mondsee. Long arrows point to row of inner membranelles of adoral zone. Short arrows point to extrusome girdle, which is complete in Limnostrombidium, but interrupted by row of inner membranelles in Pelagostrombidium. Scale bar $=10 \mu$. Fig. 5. Flask-shaped resting cyst of Pelagostrombidium from Lake Mondsee sediment sample. Lugol-fixation. Note the spines on the cyst surface and the clear plug. Scale as in Fig. 3

\section{Composition of strombidiids}

Two genera are presently known among freshwater strombidiid ciliates, namely Limnostrombidium and Pelagostrombidium (Foissner et al. 1999). We identified both taxa with the protargol technique in samples obtained from surface waters of Lake Mondsee during spring and autumn (Figs. $3 \& 4$ ). These non-quantitative preparations also served to determine relative frequencies and size ranges. In the combined samples from September 9 to 15, 1999, and in the sample from May 22, 2001 Pelagostrombidium was identified as the dominating genus (Table 1). Individuals of both genera covered the same size range, with their largest diameters ranging from 30 to $60 \mu \mathrm{m}$. Since distinguishing characters other than size and shape were not visible in Lugol-fixed specimens, we were not able to quantitatively separate

Table 1. Ratio of Pelagostrombidium:Limnostrombidium in Lake Mondsee (depth 0 to $20 \mathrm{~m}$ ) in autumn 1999 and spring 2001. Genus identification by protargol staining. Damaged specimens which could not be determined to genus are not included

\begin{tabular}{|lccc|}
\hline & $\begin{array}{c}\text { Number of } \\
\text { identified } \\
\text { strombidiids }\end{array}$ & $\begin{array}{c}\text { Pelago- } \\
\text { strombidium } \\
(\%)\end{array}$ & $\begin{array}{c}\text { Limno- } \\
\text { strombidium } \\
(\%)\end{array}$ \\
\hline Sep 9+15, 1999 & 93 & 70 & 30 \\
May 22, 2001 & 112 & 83 & 17 \\
\hline
\end{tabular}

both genera in the routine counts and, therefore, did not record strombidiid composition over the entire seasonal cycle. However, since a few specimens in each sample could be recognized unequivocally by their characteristic shape, we noticed that both genera coexisted throughout the study period.

\section{Dynamics of active strombidiids}

Strombidiid ciliates accounted for ca. $12 \%$ of the oligotrichs and for ca. $6 \%$ of total ciliate numbers. Their concentrations at 0 to $20 \mathrm{~m}$ depth varied from 50 to 2100 cells $^{-1}$ (Fig. 2). The strombidiid peak in May 2000 appeared unrelated to the phytoplankton spring bloom in April, when chl a concentrations reached 8 $\mu \mathrm{I} \mathrm{I}^{-1}$ (Fig. 2), and combined cell numbers of small cryptophytes (Rhodomonas spp. and Cryptomonas pusilla) exceeded $10^{3}$ cells $\mathrm{ml}^{-1}$. Large numbers of strombidiids developed only 5 wk later, when water temperatures at $3 \mathrm{~m}$ depth increased from 11 to $17^{\circ} \mathrm{C}$ within 2 wk. The abundance of small cryptophytes ranged from 400 to 600 cells ml ${ }^{-1}$ during the ciliate peak. A comparable strombidiid peak was not observed in April/May 2001. Strombidiid concentrations ranged from 100 to 900 cells $\mathrm{l}^{-1}$ from June through November and from 50 to 200 cells $\mathrm{l}^{-1}$ from December through mid-March. Notably, low numbers of active strombidiids were present throughout the winter months. 
Table 2. Dimensions of Pelagostrombidium cysts in sediment samples from Lake Mondsee (this study) and Lake Constance (Müller \& Wünsch 1999, unpubl. data)

\begin{tabular}{|c|c|c|c|c|c|}
\hline \multirow{2}{*}{$\begin{array}{l}\text { Location } \\
\text { Period }\end{array}$} & \multirow[t]{2}{*}{$\mathrm{n}$} & \multicolumn{2}{|c|}{ Length $(\mu \mathrm{m})$} & \multicolumn{2}{|c|}{ Width $(\mu \mathrm{m})$} \\
\hline & & Mean \pm SD & Range & Mean \pm SD & Range \\
\hline \multicolumn{6}{|l|}{ Lake Mondsee } \\
\hline Sep 9 to Oct 25, 1999 & 114 & $56 \pm 4$ & $45-62$ & $36 \pm 2$ & $30-40$ \\
\hline Oct 18 to 25,1999 & 40 & $57 \pm 3$ & $49-62$ & $36 \pm 2$ & $32-40$ \\
\hline \multicolumn{6}{|l|}{ Lake Constance } \\
\hline Apr 28 to May 5, 1997 & 30 & $67 \pm 3$ & $61-75$ & $41 \pm 1$ & $39-43$ \\
\hline Sep 22 to 29,1997 & 30 & $59 \pm 2$ & $55-61$ & $36 \pm 1$ & $33-39$ \\
\hline
\end{tabular}

\section{The species problem}

In each of the genera under investigation, namely Limnostrombidium and Pelagostrombidium (both formerly Strombidium), 2 very similar species have been described. Kahl (1932) and Foissner (1994) treated L. pelagicum as a form of $L$. viride, whereas Krainer (1991) and Foissner et al. (1999) defined it as a separate species. Distinguishing features according to Foissner et al. (1999) are listed in Table 3.

\section{Cyst formation}

We observed only 1 type of strombidiid cyst, which by its flask shape, clear plug and spines was identified as the resting stage of Pelagostrombidium (Fig. 5). Cyst dimensions are presented in Table 2 together with earlier data from the Lake Constance population (Müller \& Wünsch 1999). The Mann-Whitney rank sum test revealed significant differences in both length and width between spring cysts from Lake Constance and autumn cysts from both lakes $(\mathrm{p}<0.001)$. Cysts collected during the autumn maxima in Lake Constance and Lake Mondsee differed slightly in length $(p=0.006)$ but not in width $(p=$ 0.967). Thus, the overall size difference between autumn cysts from both lakes was small compared to the seasonal size difference within the Lake Constance population.

High cyst production occurred in October/November of 1999 and 2000, with a maximum rate of $2 \times 10^{5}$ cysts $\mathrm{m}^{-2} \mathrm{~d}^{-1}$ (18 to 25 October 1999). One smaller peak was recorded in August 2000. Virtually no cysts were found from February to July 2000, whereas in April/ May of 2001 encystment occurred at a very low rate, never exceeding 4000 cyst $\mathrm{m}^{-2} \mathrm{~d}^{-1}$.
While most of these features are overlapping, the characters $<$ presence/absence of sequestered plastids $>$ and $<$ numbers of basal body pairs in the ventral ciliary row $>$ seem to be decisive. However, with the methods used in our study, we were not able to recognize these details. Considering cell size, which rarely exceeded $60 \mu \mathrm{m}$, we believe that the majority of Limnostrombidium individuals in Lake Mondsee belong to the species

Table 3. Criteria separating the species Limnostrombidium viride and L. pelagicum according to Foissner et al. (1999)

\begin{tabular}{|lcc|}
\hline & L. viride & L. pelagicum \\
\hline Length $(\mu \mathrm{m})$ & $40-90$ & $30-60$ \\
Width $(\mu \mathrm{m})$ & $30-55$ & $25-45$ \\
Micronuclei & $1-2$ & $1-3$ \\
Color & Greenish & Colorless or \\
& to yellow- & greenish-gray or \\
& green & reddish brown \\
Sequestered plastids & Yes & No \\
Colourful granules & No & Often \\
Basal body pairs in & $13-18$ & $7-10$ \\
ventral ciliary row & $6-16$ & $8-12$ \\
Inner buccal membranelles & $6-10$ \\
\hline
\end{tabular}

\section{DISCUSSION}

We present the second field study on encystment of strombidiid ciliates in freshwater, and the first one which covers an entire annual period. Our records during summer and autumn agree with observations of Müller \& Wünsch (1999) from pre-alpine Lake Constance, whereas data collected during the spring period are in contrast to this earlier study. In the following, we will discuss the seasonal dynamics of strombidiids, comparing results from both field studies.
Table 4. Criteria separating the species Pelagostrombidium fallax and $P$. mirabile according to Foissner et al. (1999). In parentheses: according to Krainer (1991) and Foissner (1994)

\begin{tabular}{|c|c|c|}
\hline & P. fallax & P. mirabile \\
\hline Size $(\mu \mathrm{m})$ & $\begin{array}{c}40-90 \times 40-80 \\
(60 \times 50)\end{array}$ & $\begin{array}{c}30-70 \times 25-50 \\
(45 \times 30)\end{array}$ \\
\hline Color & $\begin{array}{c}\text { Orange } \\
\text { (reddish brown) }\end{array}$ & $\begin{array}{l}\text { Yellowish-green } \\
\text { (greenish gray } \\
\text { to orange yellow) }\end{array}$ \\
\hline $\begin{array}{l}\text { Extension of row of } \\
\text { buccal membranell }\end{array}$ & $\begin{array}{l}\text { Ending below mid-body } \\
\text { (at least half cell length) }\end{array}$ & $\begin{array}{l}\text { Ending below mid-body } \\
\text { (third of cell length) }\end{array}$ \\
\hline $\begin{array}{l}\text { Number of buccal } \\
\text { membranelles }\end{array}$ & $\begin{array}{c}19-22 \\
(19-22)\end{array}$ & $\begin{array}{c}12-17 \\
(12-15)\end{array}$ \\
\hline Polysaccharid plates & $\begin{array}{l}\text { Polygonal } \\
\text { (polygonal) }\end{array}$ & $\begin{array}{l}\text { Polygonal } \\
\text { (square) }\end{array}$ \\
\hline
\end{tabular}


(or form) L. pelagicum. In contrast, Müller \& Wünsch (1999) encountered a large-sized population in Lake Constance (up to $100 \mu \mathrm{m}$ in length), which they identified as $L$. viride.

Criteria separating Pelagostrombidium mirabile from $P$. fallax have been changed recently (Table 4). Müller \& Wünsch (1999) observed 'a long row of buccal membranelles $(>16)$ extending at least half cell length internally' and 'polygonal polysaccharide plates' in the Lake Constance population. Based on these characters, the ciliates were identified as P. fallax according to Krainer (1991) and Foissner (1994). However, using the more recent definitions by Foissner et al. (1999), the same criteria could also lead to $P$. mirabile (Table 4). These authors argue that the Lake Constance population has been misidentified. It should be considered, however, that in the list of Foissner et al. (1999) only 2 decisive characters remain, namely $<$ numbers of buccal membranelles $>$ and $<$ color $>$. Since little is known about the variability of these characters, it cannot be excluded that $P$. fallax and $P$. mirabile might be synonyms, as already considered by Kahl (1932).

The Pelagostrombidium population in Lake Mondsee, in our judgement, was identical to that observed in Lake Constance. For the reasons explained above, we did not attempt identification to the species level.

\section{Cyst identification}

Our identification of Pelagostrombidium cysts was corroborated by laboratory experiments; by live observation, Müller (2002, this issue) identified excysting ciliates from a sediment sample collected during the present field study as Pelagostrombidium. In the present investigation, we did not find the large Limnostrombidium viride cysts (mean length $96 \pm$ $5 \mu \mathrm{m}$ ) which have been described in Lake Constance. This is not surprising, since active strombidiids of a similar size did not occur in Lake Mondsee. Limnostrombidium cysts in this lake, if there are any, should be within the same size range as those of Pelagostrombidium. Other differences than size, separating the 2 cyst types in Lake Constance, were surface structure (hardly visible with light microscopy) and features of the plug. Pelagostrombidium cysts had a clear plug, whereas the plug of Limnostrombidium cysts was composed of several bubbles enclosed within a larger sphere (cf. Figs. 4 \& 5 in Müller \& Wünsch 1999). Since all cysts recorded in Lake Mondsee had the typical Pelagostrombidium plug (Fig. 5), we conclude that throughout our study the Limnostrombidium population did not form cysts.

\section{Strombidiid dynamics in summer/autumn}

From July through November numbers of active strombidiids in Lake Mondsee were within the same range as reported from Lake Constance. The timing and magnitude of cyst formation in both lakes were also comparable: significant cyst fluxes were observed from September through November, with a maximum rate of $2 \times 10^{5}$ cysts $\mathrm{m}^{-2} \mathrm{~d}^{-1}$ (Lake Constance: September 22 to 29, 1997; Lake Mondsee: October 18 to 25, 1999). Notably, an additional peak occurred in August 2000 in Lake Mondsee during a period of high water temperatures $\left(>20^{\circ} \mathrm{C}\right.$ at $3 \mathrm{~m}$ depth). This observation challenges the hypothesis of Müller \& Wünsch (1999), who suggested that high water temperatures may impede encystment of Pelagostrombidium.

Müller \& Wünsch (1999) crudely estimated the quantitave importance of cyst production relative to total production of the active Pelagostrombidium population in Lake Constance. Assuming generation times in the range of 24 to $120 \mathrm{~h}$, their model calculation yielded ratios of cyst production: total population production of 1 to $6 \%$, when averaged over 3 mo in autumn, and of 16 to $80 \%$ during the peak of encystment in September 1997. The same model calculation, applied to the autumn period in Lake Mondsee, should yield similar results, since concentrations of active strombidiids and cysts fluxes were within the same order of magnitude. A more precise estimate of the quantitative importance of cyst formation could be achieved only by measuring in situ production rates in parallel to records of cyst fluxes.

\section{Strombidiid dynamics in winter}

Low numbers of active strombidiids were always present throughout the winter months, i.e. survival of the population during the cold season did not rely entirely on the resting stages. Very few cysts were found in the traps during this period. While these could have been produced in winter, it appears more likely that they were leftovers from the cyst production in autumn, which had not yet sedimented.

\section{Strombidiid dynamics in spring}

Müller \& Wünsch (1999) reported a highly significant correlation of strombidiid abundance with chl a in Lake Constance from April through mid-June 1997,

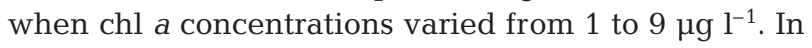
contrast, the strombidiids in Lake Mondsee did not respond to the chl a maximum (up to $8 \mu \mathrm{g} \mathrm{l}^{-1}$ ) in April 
2000 (Fig. 2). Phytoplankton counts revealed that diatoms and small cryptomonads contributed ca. 69 and 25, respectively, to algal cell concentrations during this bloom, and that small cryptomonads, a preferred food of strombidiid ciliates (Müller \& Geller 1993, Müller 1996), reached concentrations of up to $10^{6}$ cells $\mathrm{l}^{-1}$. Similar cryptomonad concentrations are typical for the phytoplankton spring bloom in Lake Constance (Weisse et al. 1990). Notably, the entire ciliate community in Lake Mondsee (mainly algivorous taxa), responded only weakly to the chl a peak in April 2000 (Fig. 1). During the present study, we did not collect any data which could explain the differing response of strombidiid ciliates (and of planktonic ciliates in general) to cryptomonad spring peaks of similar magnitude in both lakes. Differences in the community composition of the crustacean zooplankton (see 'Introduction') could have played a role. Since the crustaceans in Lake Mondsee are known to be dominated by copepods (Dokulil et al. 1990, Nauwerck 1991), which may act as efficient predators of ciliates (Wickham 1995), copepod grazing could have caused the delay in the development of the ciliate spring community in Lake Mondsee.

Strombidiid encystment during spring is, most probably, linked to food availability. In Lake Constance, the strombidiid maximum and the onset of cyst formation were recorded at the culmination of the phytoplankton spring bloom. Cyst production increased further when food concentrations declined. Müller (1996) observed the same pattern in batch cultures of Pelagostrombidium from Lake Constance with cryptomonads as food; cyst formation started at high food levels, but was enhanced during phases of decreasing prey concentrations. In Lake Mondsee, in contrast, strombidiids developed with a delay of $5 \mathrm{wk}$ and peaked when chl a values had decreased to $<3 \mu \mathrm{gl}^{-1}$. Although strombidiids in Lake Mondsee did not form cysts in spring 2000, and only a negligible number in spring 2001, descendants of the same Pelagostrombidium population, grown in well-fed laboratory cultures, produced large numbers of cysts at the same time, as reported by Müller (2002).

\section{CONCLUSIONS}

A pronounced seasonality of cyst production is commonly observed in field studies on dormancy of marine and freshwater loricate and aloricate oligotrich ciliates (for a review see Müller 2000). Cysts formed in late summer or autumn are interpreted as 'overwintering stages' (e.g. Reid \& John 1978, Paranjape 1980), whereas encystment in spring is assumed to serve as a defense mechanism against predation (e.g. Reid 1987).
The data on freshwater strombidiids collected in Lake Mondsee (this study) and in Lake Constance (Müller \& Wünsch 1999) fit into this scheme. They suggest that the environmental 'spring signal' causing encystment of freshwater strombidiids is a period of high food availability. Since phytoplankton blooms are exploited not only by planktonic ciliates, but also by rotifers and crustaceans, and since metazoa have longer generation times than protozoa, it may be an efficient survival strategy of the ciliates to encyst and sink to the lake bottom prior to mass development of their metazoan predators. While in Lake Constance both genera, Limnostrombidium and Pelagostrombidium, showed a strong response to this 'spring signal', the strombidiids in Lake Mondsee apparently missed it due to a delay in their development.

The nature of the environmental 'autumn signal' triggering encystment of Pelagostrombidium at the end of the growing season remains unknown. Comparing the results from both field studies, we conclude that this signal was of similar strength in both lakes. Only Pelagostrombidium responded to this 'autumn signal'. Müller (2002) presents experimental evidence that the majority of cysts formed in late autumn will excyst a few months later in early spring. The term 'overwintering stage' for the autumn cysts therefore seems to be adequate.

Acknowledgements. This study was supported by the Jubiläumsfond of the Österreichische Nationalbank (Project 7792 - Weisse). The sediment traps were provided by the Limnological Institute Konstanz (Prof. Dr. K. O. Rothhaupt). Claudia Skolaut (Institute for Limnology, Mondsee) measured chlorophyll a concentrations and contributed unpublished data on phytoplankton composition. Bettina Sonntag (Limnological Institute of the University of Innsbruck) determined ciliate cell concentrations. Comments of 3 anonymous referees helped to improve the manuscript.

\section{LITERATURE CITED}

Bloesch J, Burns NM (1980) A critical review of sedimentation trap technique. Schweiz Z Hydrol 42:15-55

Dokulil M, Skolaut C (1986) Succession of phytoplankton in a deep stratifying lake: Mondsee, Austria. Hydrobiologia 138:9-24

Dokulil M, Herzig A, Jagsch A (1990) Trophic relationships in the pelagic zone of Mondsee, Austria. Hydrobiologia 191: $199-212$

Fenchel T (1987) Ecology of protozoa. The biology of freeliving phagotrophic protists. In: Brock TD (ed) Brock/ Springer series in contemporary bioscience. Science Tech Publishers, Madison, WI

Foissner W (1991) Basic light and scanning electron microscopic methods for taxonomic studies of ciliated protozoa. Europ J Protistol 27:313-330

Foissner W (1994) Progress in taxonomy of planktonic freshwater ciliates. Mar Microb Food Webs 8:9-35

Foissner W, Berger H, Schaumburg J (1999) Identification and 
ecology of limnetic planktonic ciliates. Informationsberichte des Bayer Landesamtes für Wasserwirtschaft, Munich, Heft 3/99

Häse C, Gaedke U, Seifried A, Beese B, Tilzer MM (1998) Phytoplankton response to re-oligotrophication in large and deep Lake Constance: photosynthetic rates and chlorophyll concentrations. Arch Hydrobiol Spec Issues Advanc Limnol 53:159-178

IGKB (Internationale Gewässerschutzkommission für den Bodensee) (2000) Limnologischer Zustand des Bodensees. Jahresber Int Gewaesserschutzkomm Bodensee 27:1-81

Kahl A (1932) Urtiere oder Protozoa. I: Wimpertiere oder Ciliata (Infusoria). 3. Spirotricha. In: Dahl F (ed) Die Tierwelt Deutschlands. G. Fischer, Jena, 25:399-650

Kim YO, Taniguchi A (1995) Excystment of the oligotrich ciliate Strombidium conicum. Aquat Microb Ecol 9:149-156

Krainer KH (1991) Contributions to the morphology, infraciliature and ecology of the planktonic ciliates Strombidium pelagicum n.sp., Pelagostrombidium mirabile (Penard, 1916) n.g., n. comb. and Pelagostrombidium fallax (Zacharias, 1896) n.g., n. comb., (Ciliophora, Oligotrichida). Europ J Protistol 27:60-70

Krainer KH (1995) Taxonomische Untersuchungen an neuen und wenig bekannten planktischen Ciliaten (Protozoa: Ciliophora) aus Baggerseen in Österreich. Lauterbornia 21:39-68

Lampert W (1978) Climatic conditions and planktonic interactions as factors controlling the regular succession of spring algal blooms and extremely clear water in Lake Constance. Verh Internat Verein Limnol 20:969-974

Müller H (1989) The relative importance of different ciliate taxa in the pelagic food web of Lake Constance. Microb Ecol 18:261-273

Müller H (1996) Encystment of the freshwater ciliate Pelagostrombidium fallax (Ciliophora, Oligotrichida) in laboratory culture. Aquat Microb Ecol 11:289-295

Müller H (2000) Evidence of dormancy in planktonic oligotrich ciliates. Verh Internat Verein Limnol 27: 3206-3209

Müller H (2002) Laboratory study of the life cycle of a fresh-

Editorial responsibility: Karel Šimek,

České Budějovice, Czech Republic water strombidiid ciliate. Aquat Microb Ecol 29:189-197

Müller H, Geller W (1993) Maximum growth rates of aquatic ciliated protozoa: the dependence on body size and temperature reconsidered. Arch Hydrobiol 126:315-327

Müller H, Wünsch C (1999) Seasonal dynamics of cyst formation of pelagic strombidiid ciliates in a deep prealpine lake. Aquat Microb Ecol 17:37-47

Müller H, Schöne A, Pinto-Coelho RM, Schweizer A, Weisse $\mathrm{T}$ (1991) Seasonal succession of ciliates in Lake Constance. Microb Ecol 21:119-138

Nauwerck A (1991) Zooplankton changes in Mondsee. Verh Internat Verein Limnol 24:974-979

Nusch EA (1980) Comparison of different methods for chlorophyll and phaeopigment determinations. Arch Hydrobiol, Beih Ergebn Limnol 14:14-36

OECD (Organisation for Economic Co-operation and Development) (1982) Eutrophication of waters. Monitoring, assessment and control. OECD Publications, Paris, p 155

Paranjape MA (1980) Occurrence and significance of resting cysts in a hyaline tintinnid, Helicostomella subulata (Ehre.) Jorgensen. J Exp Mar Biol Ecol 48:23-33

Reid PC (1987) Mass encystment of a planktonic oligotrich ciliate. Mar Biol 95:221-230

Reid PC, John AWG (1978) Tintinnid cysts. J Mar Biol Assoc UK 58:551-557

Salbrechter M, Arndt H (1994) The annual cycle of protozooplankton in the alpine, mesotrophic Lake Mondsee (Austria). Mar Microb Food Webs 8:217-234

Schwarz K, Jagsch A (1998) Die Seen Oberösterreichs. Bundesamt für Wasserwirstschaft, Institut für Gewässerökologie, Fischereibiologie und Seenkunde, Scharfling, Austria (CD ROM)

Weisse T, Müller H, Pinto-Coelho R, Schweizer A, Springmann D, Baldringer G (1990) Response of the microbial loop to the phytoplankton spring bloom in a large prealpine lake. Limnol Oceanogr 35:781-794

Wickham SA (1995) Trophic relations between cyclopoid copepods and ciliated protists: complex interactions link the microbial and classic food webs. Limnol Oceanogr 40: $1173-1181$

Submitted: February 11, 2002; Accepted: June 18, 2002 Proofs received from author(s): August 27, 2002 